University of Nebraska - Lincoln

DigitalCommons@University of Nebraska - Lincoln

2011 Bird Strike North America Conference, Niagara Falls

Bird Strike Committee Proceedings

$9-2011$

\title{
Interspecific variation in wildlife hazards to aircraft: Implications for airport wildlife management
}

Travis L. DeVault

USDA, APHIS, Wildlife Services, Travis.L.DeVault@aphis.usda.gov

Jerrold L. Belant

USDA, APHIS, Wildlife Services

Bradley F. Blackwelll

USDA/APHIS/WS National Widldlife Research Center, bradley.f.blackwell@aphis.usda.gov

Thomas W. Seamans

USDA, APHIS, Wildlife Services, thomas.w.seamans@aphis.usda.gov

Follow this and additional works at: https://digitalcommons.unl.edu/birdstrike2011

DeVault, Travis L.; Belant, Jerrold L.; Blackwelll, Bradley F.; and Seamans, Thomas W., "Interspecific variation in wildlife hazards to aircraft: Implications for airport wildlife management" (2011). 2011 Bird Strike North America Conference, Niagara Falls. 11.

https://digitalcommons.unl.edu/birdstrike2011/11

This Article is brought to you for free and open access by the Bird Strike Committee Proceedings at DigitalCommons@University of Nebraska - Lincoln. It has been accepted for inclusion in 2011 Bird Strike North America Conference, Niagara Falls by an authorized administrator of DigitalCommons@University of Nebraska Lincoln. 
Interspecific variation in wildlife hazards to aircraft: Implications for airport wildlife management

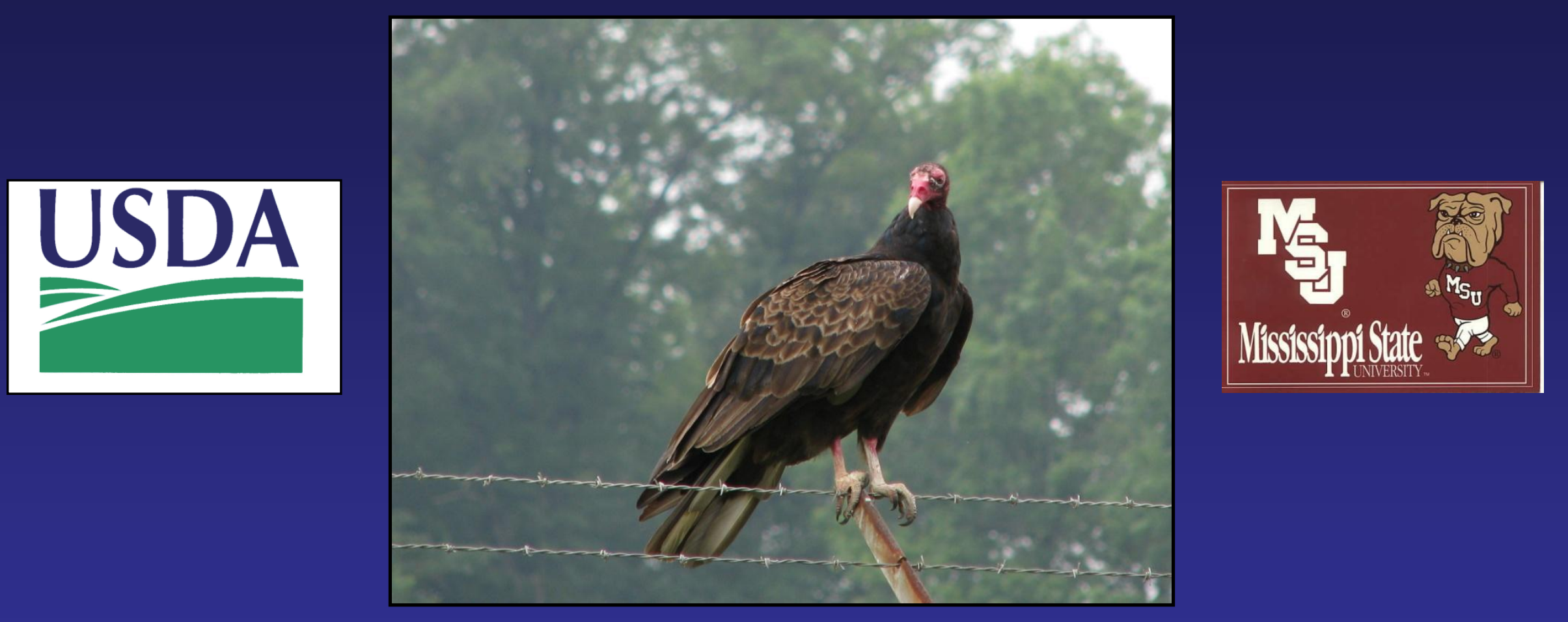

\section{Travis L. DeVault, Jerrold L. Belant, Bradley F. Blackwell, and Thomas W. Seamans}




\section{Background}

$\rightarrow 70 \%$ of all wildlife strikes with aircraft occur at $<500 \mathrm{ft}$, where management at the airport can be effective.

+ At least 415 bird and 35 terrestrial mammal species were struck by aircraft from 1990-2009.

t Overall, $14 \%$ of all strikes with birds and $61 \%$ of all strikes with mammals caused some damage.

t But, the severity and probability of damage is species-specific.

† To better prioritize management (e.g., habitat management, landuse planning, non-lethal dispersal), an improved understanding of which species are most hazardous is needed. 


\section{Research questions}

† Which species are most hazardous?

† That is, which species are most likely to cause some type of damage to the aircraft when struck?

+ How do body mass, body density, and flocking behavior contribute to hazard level?

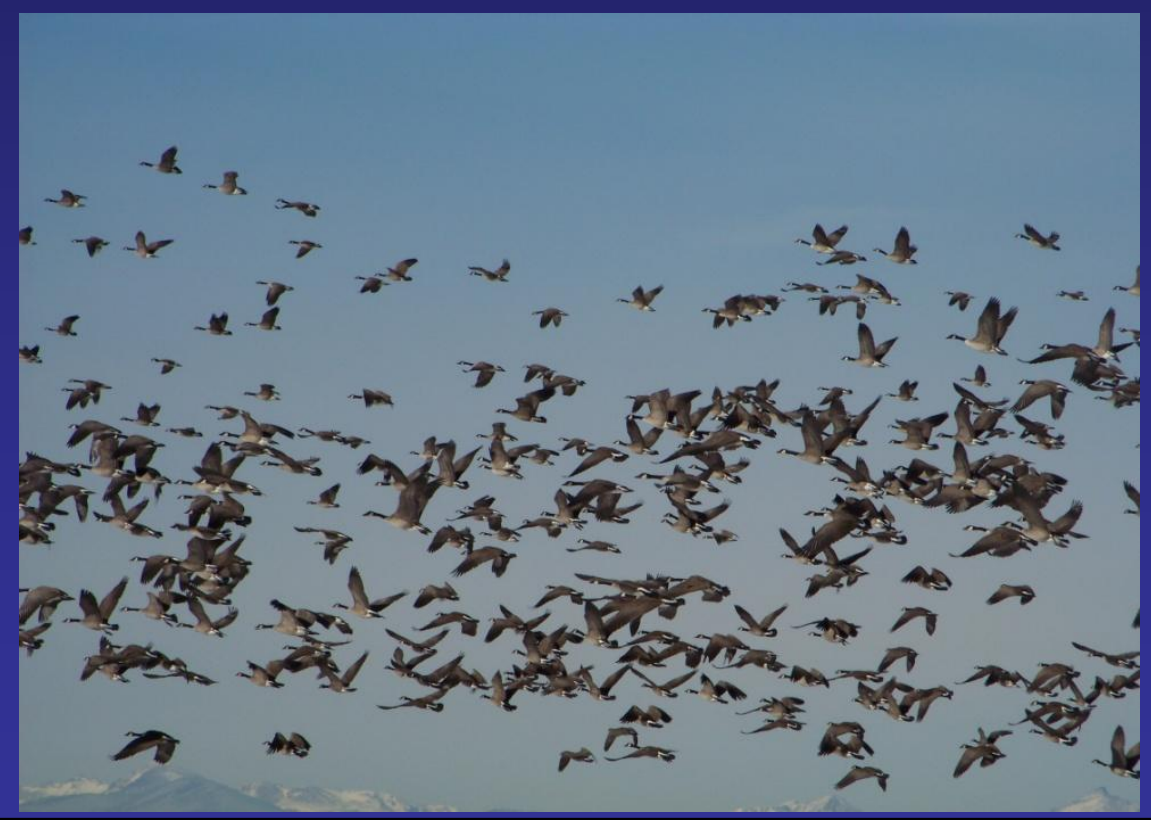




\section{Building on previous research}

t Dolbeer, R.A., S.E. Wright, and E.C. Cleary. 2000. Ranking the hazard level of wildlife species to aviation. Wildlife Society Bulletin 28:372-378.

t $\sim 18,000$ records in the database

$\uparrow 21$ wildlife species/groups considered

$\rightarrow$ Dolbeer, R.A., and S.E. Wright. 2009. Safety management systems: How useful will the FAA National Wildlife Strike Database be? Human-Wildlife Conflicts 3:167-178.

† Did not use a composite hazard score

† Zakrajsek, E.J., and J.A. Bissonette. 2005. Ranking the risk of wildlife species hazardous to military aircraft. Wildlife Society Bulletin 33:258-264.

H Used the number of damaging strikes and cost as criteria 


\section{Methods}

† Used FAA National Wildlife Strike Database records: 1990-2009

† 99,411 total strikes

$\rightarrow$ Summarized strikes for $\mathbf{7 7}$ species or groups with $\geq \mathbf{2 0}$ records

† Only used strikes $\leq 500 \mathrm{ft} \mathrm{AGL}$ (in the airport environment)

$\rightarrow$ Reduced sample size to 23,503 reports

$\rightarrow$ Variables used in ranking

$\uparrow \%$ of strikes with damage

$\uparrow \%$ of strikes with substantial damage

$+\%$ of strikes with effect on flight (EOF)

† Species were ranked and a relative hazard score was calculated

$\rightarrow$ For birds, we assessed effects of body mass, body density, and group size on relative hazard scores 


\section{Top 10 most hazardous birds and mammals}

\begin{tabular}{|c|c|c|c|c|c|c|}
\hline Species & $\begin{array}{l}\text { Total strikes } \\
\text { reported }\end{array}$ & $\begin{array}{l}\% \text { with } \\
\text { damage }\end{array}$ & $\begin{array}{l}\% \text { with } \\
\text { substantial } \\
\text { damage }\end{array}$ & $\%$ with EOF & $\begin{array}{l}\text { Composite } \\
\text { rank }\end{array}$ & $\begin{array}{l}\text { Relative } \\
\text { hazard } \\
\text { score }\end{array}$ \\
\hline Mule deer & 47 & 96 & 38 & 83 & 1 & 100 \\
\hline White-tailed deer & 814 & 87 & 36 & 68 & 2 & 88 \\
\hline Domestic dog & 21 & 53 & 26 & 75 & 3 & 7 \\
\hline Other geese* & 20 & 68 & 32 & 32 & 4 & 61 \\
\hline Canada goose & 776 & 51 & 16 & 34 & 5 & 46 \\
\hline Turkey vulture & 159 & 46 & 16 & 34 & 5 & 4 \\
\hline Other ducks* & 77 & 49 & 24 & 30 & 7 & 48 \\
\hline Great horned owl & 29 & 52 & 16 & 27 & 8 & 4 \\
\hline $\begin{array}{l}\text { Double-crested } \\
\text { cormorant }\end{array}$ & 24 & 52 & 13 & 29 & 8 & 43 \\
\hline Brown pelican & 31 & 35 & 13 & 38 & 10 & \\
\hline
\end{tabular}




\section{Top 15 most hazardous birds}

\begin{tabular}{|c|c|c|c|c|c|}
\hline Species & $\begin{array}{l}\text { Total strikes } \\
\text { reported }\end{array}$ & $\begin{array}{l}\text { Composite } \\
\text { rank }\end{array}$ & $\begin{array}{c}\text { Relative } \\
\text { hazard score }\end{array}$ & Body mass (g) & $\begin{array}{l}\% \text { of strikes } \\
\text { with mult. } \\
\text { birds }\end{array}$ \\
\hline Other geese* & 20 & 1 & 100 & 2290 & 60.0 \\
\hline Canada goose & 776 & 2 & 76 & 3564 & 47.9 \\
\hline Other ducks* & 77 & 2 & $7 \varepsilon$ & 916 & 46.8 \\
\hline Turkey vulture & 159 & 2 & 73 & 1467 & 9.0 \\
\hline $\begin{array}{l}\text { Double-crested } \\
\text { cormorant }\end{array}$ & 24 & 5 & 71 & 1674 & 16.7 \\
\hline Great horned owl & 29 & 5 & 72 & 1309 & 3.4 \\
\hline Brown pelican & 31 & 7 & 66 & 3348 & 9.7 \\
\hline Sandhill crane & 66 & 8 & 61 & 5571 & 44.6 \\
\hline Glaucous-winged gull & 27 & 9 & 64 & 1010 & 25.9 \\
\hline Wild turkey & 38 & 9 & 65 & 5811 & 23.7 \\
\hline Bald eagle & 74 & 11 & $5 s$ & 4740 & 12.2 \\
\hline Great black-backed gull & 20 & 12 & 53 & 1659 & 15.0 \\
\hline Osprey & 77 & 13 & 53 & 1485 & 2.6 \\
\hline Great blue heron & 132 & 14 & 51 & 2390 & 2.3 \\
\hline Ring-necked pheasant & 45 & 15 & 47 & 1135 & 8.9 \\
\hline
\end{tabular}




\section{What contributes to hazard level?}

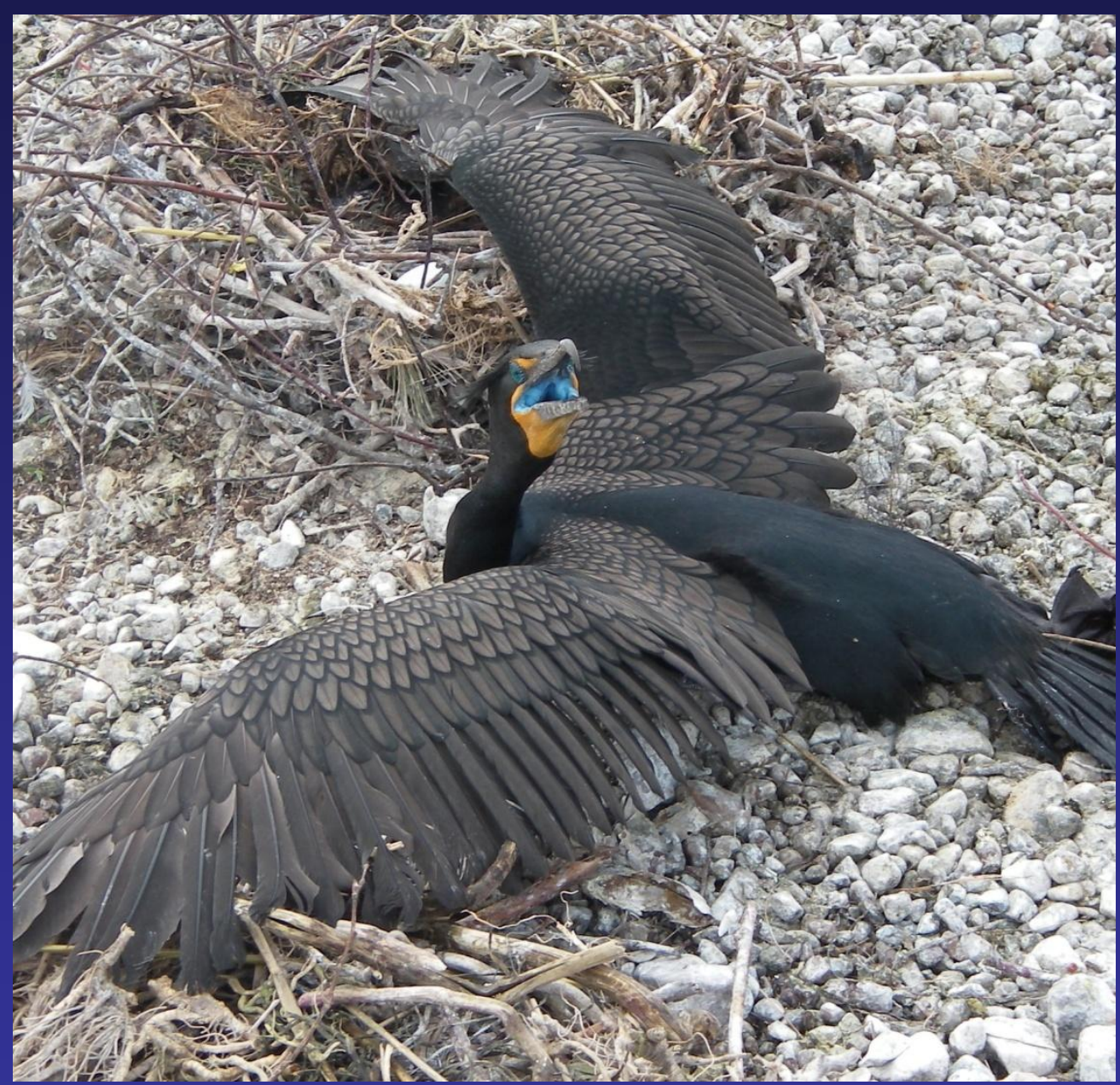

Double-crested Cormorant on nest 


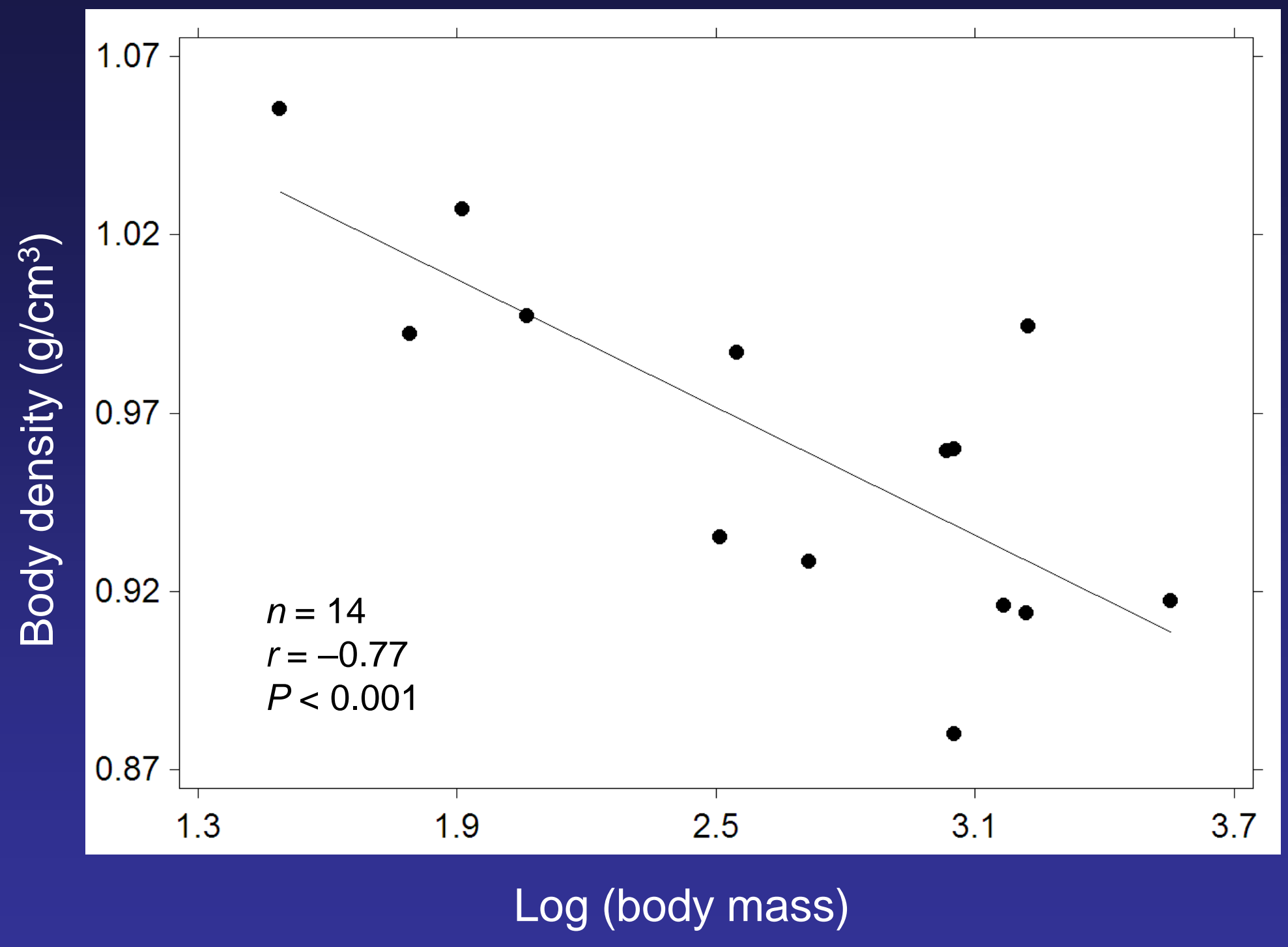




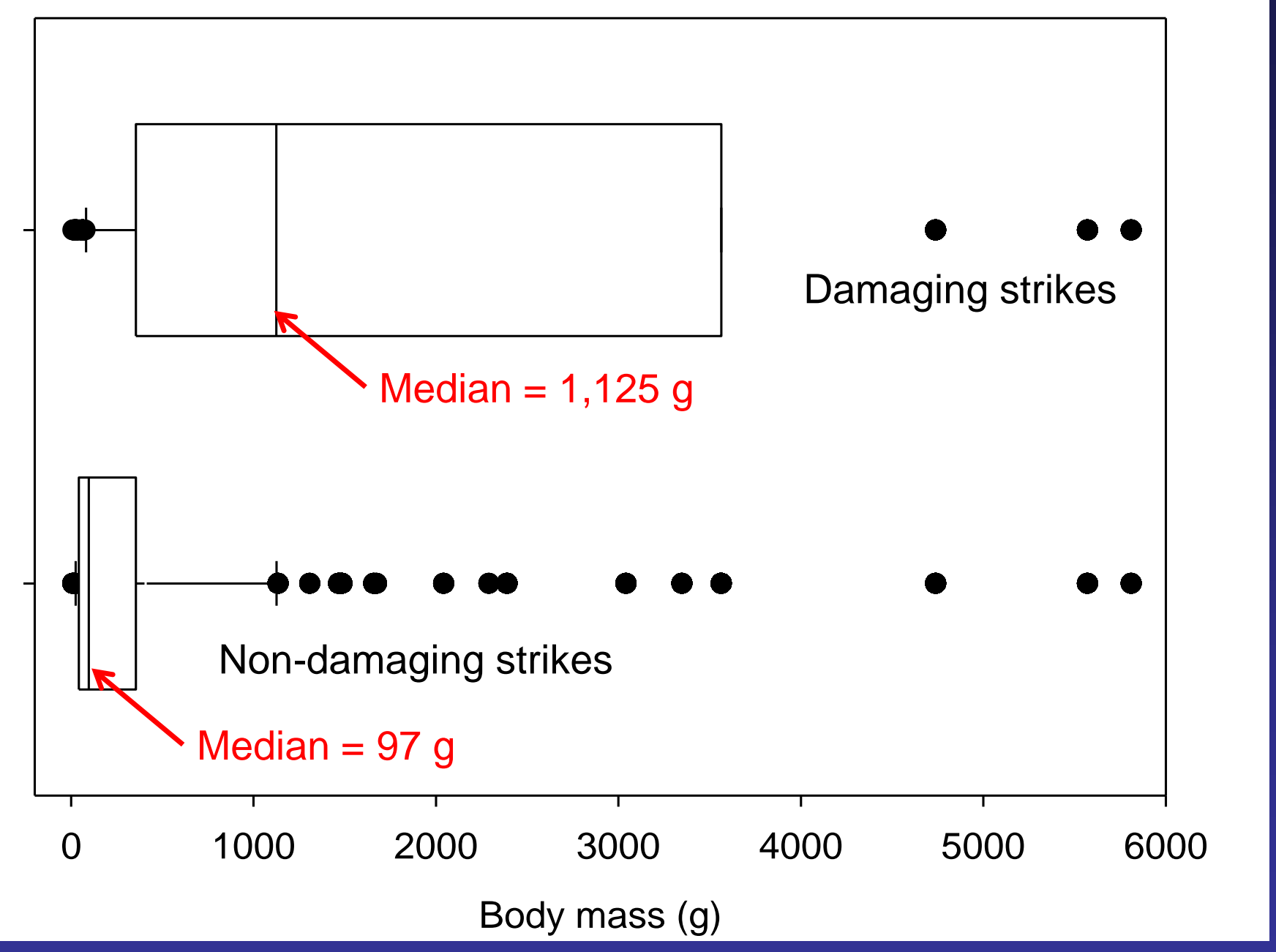




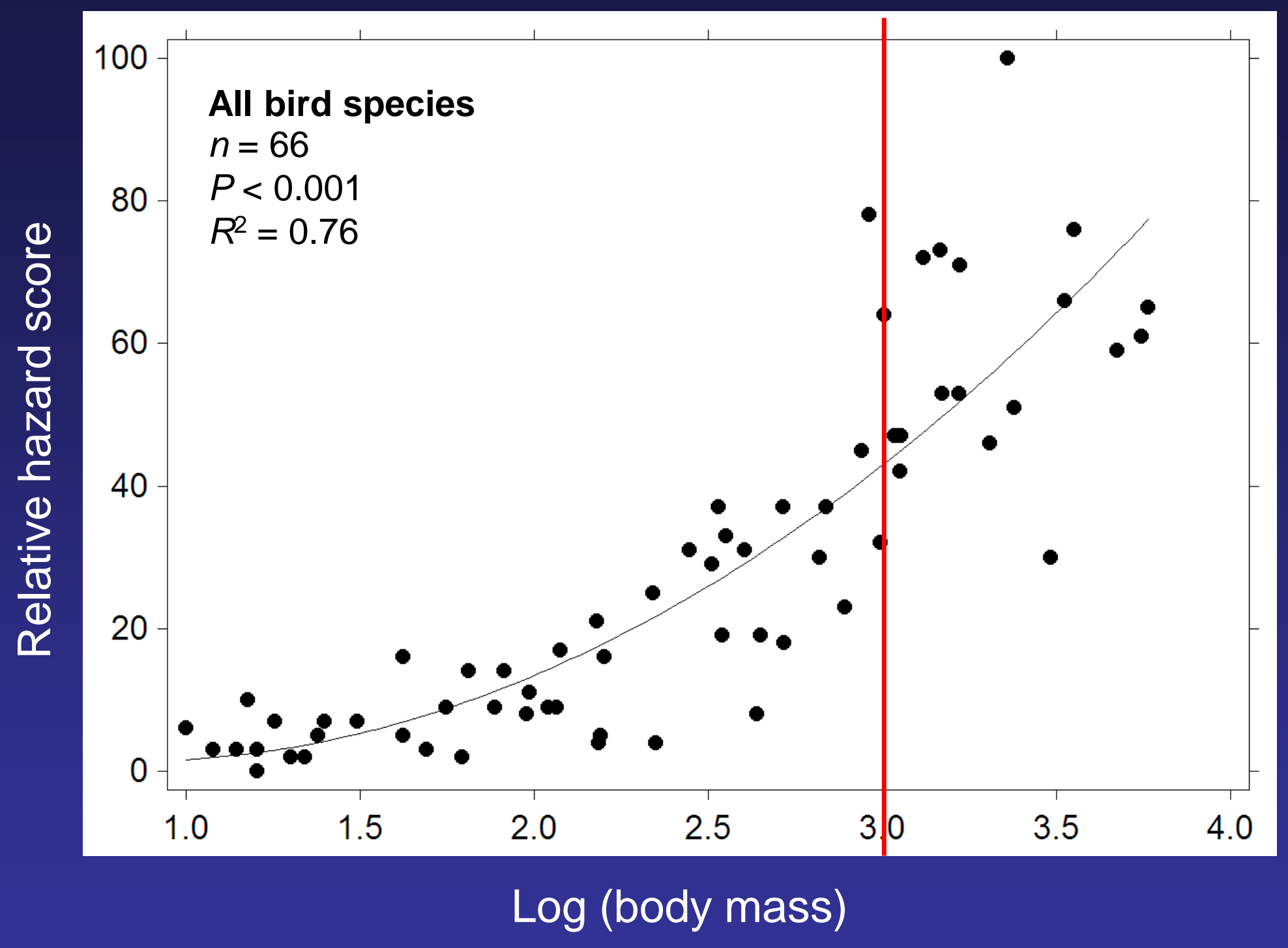




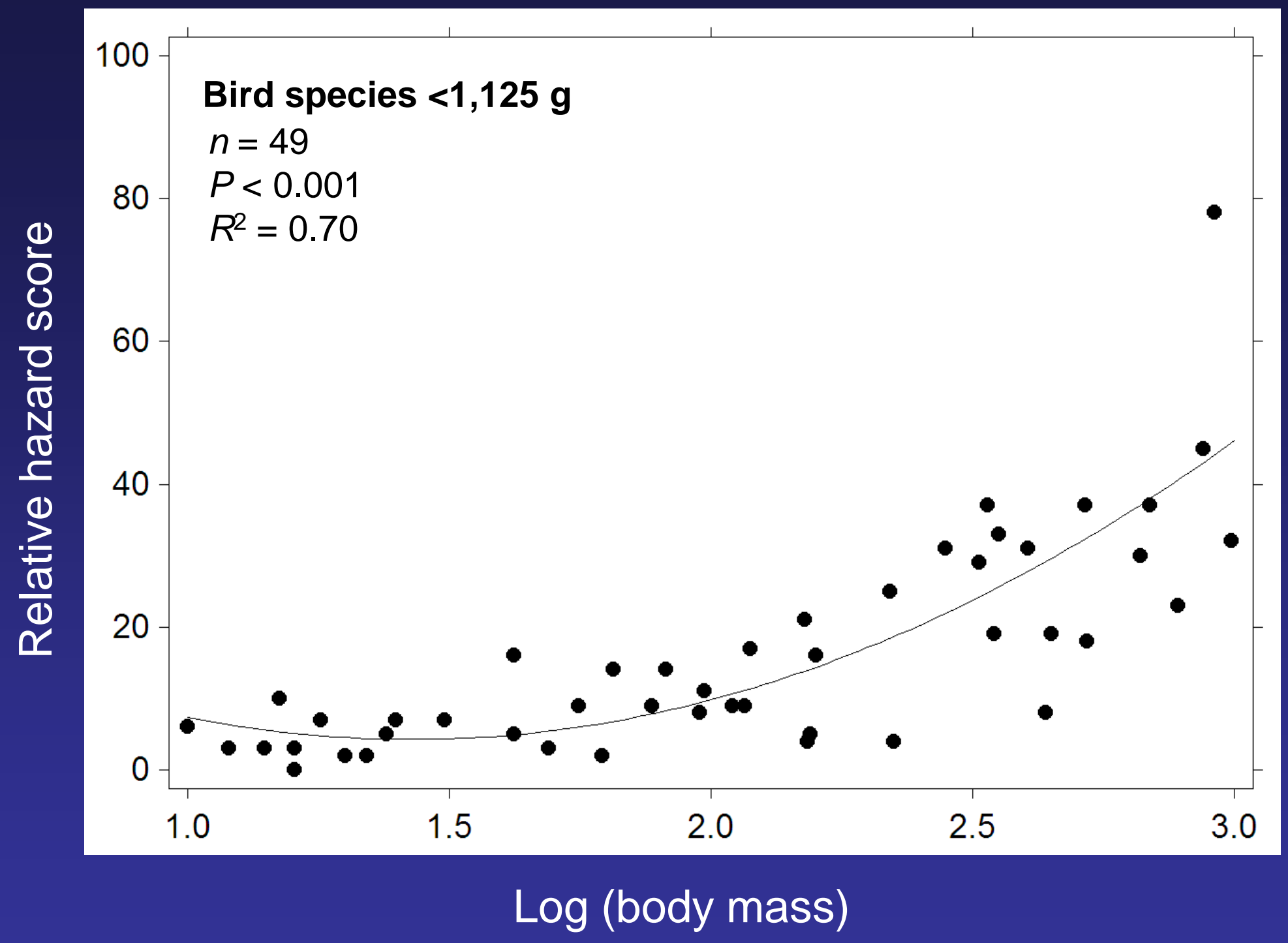




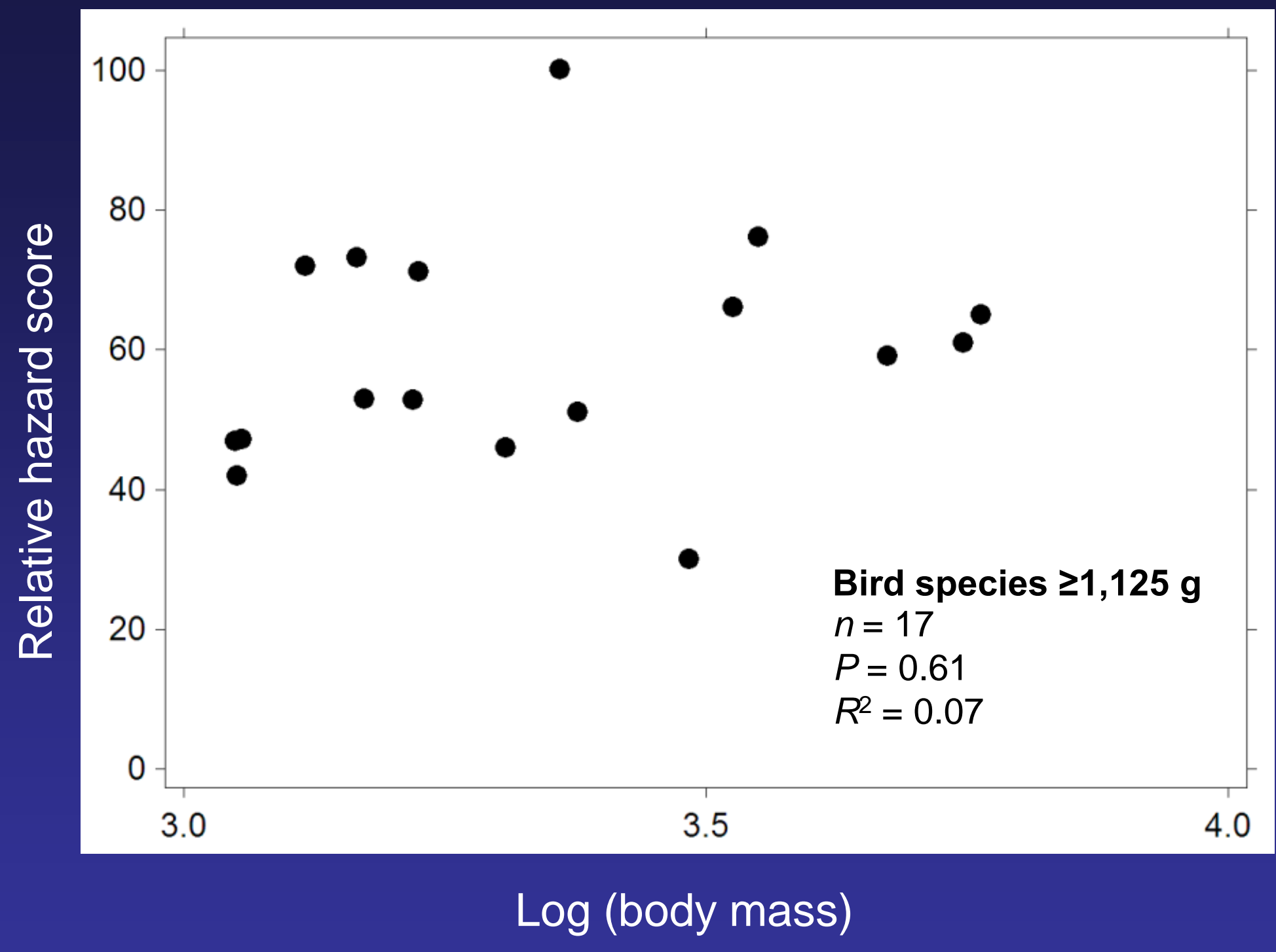




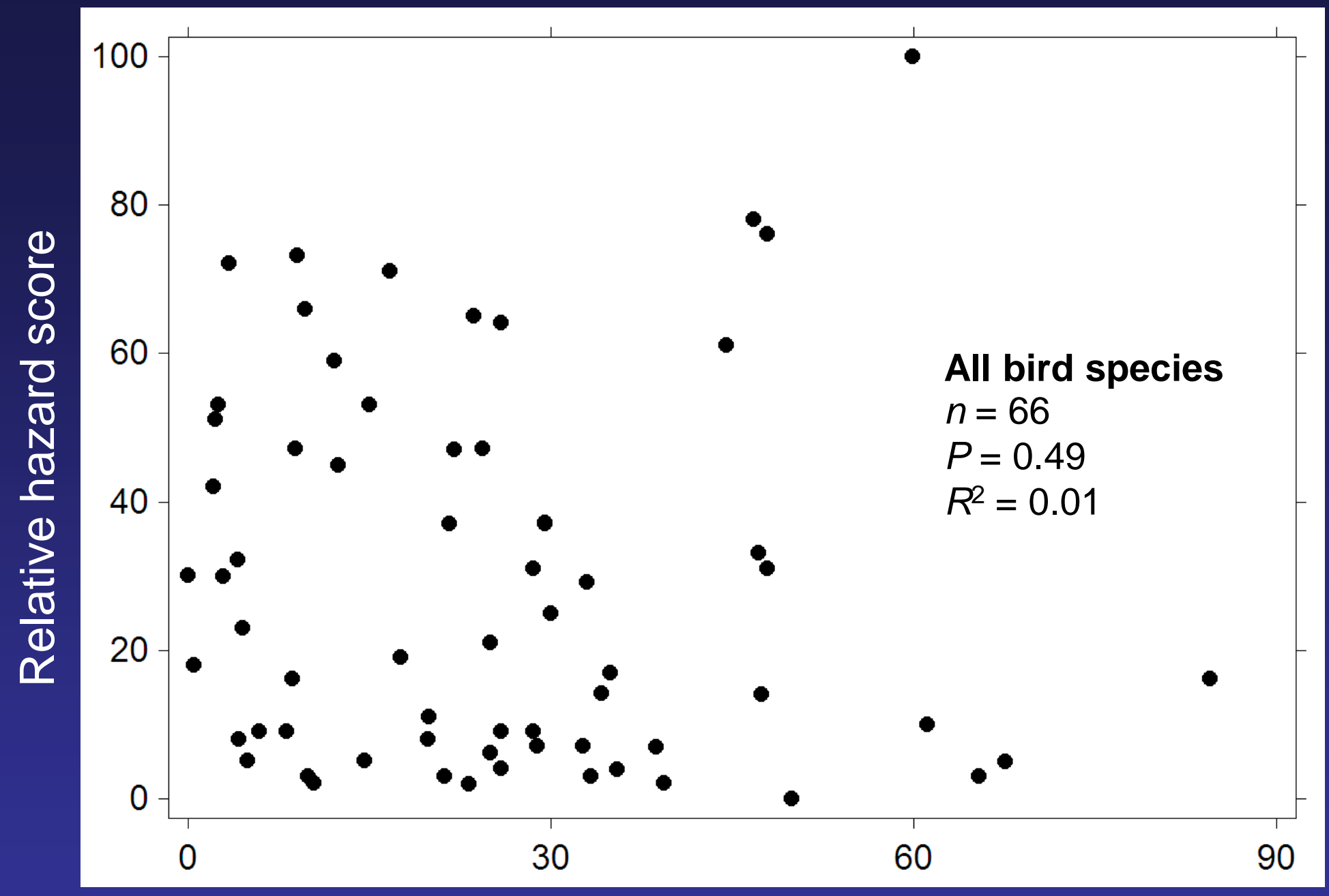

$\%$ of strikes involving multiple birds 


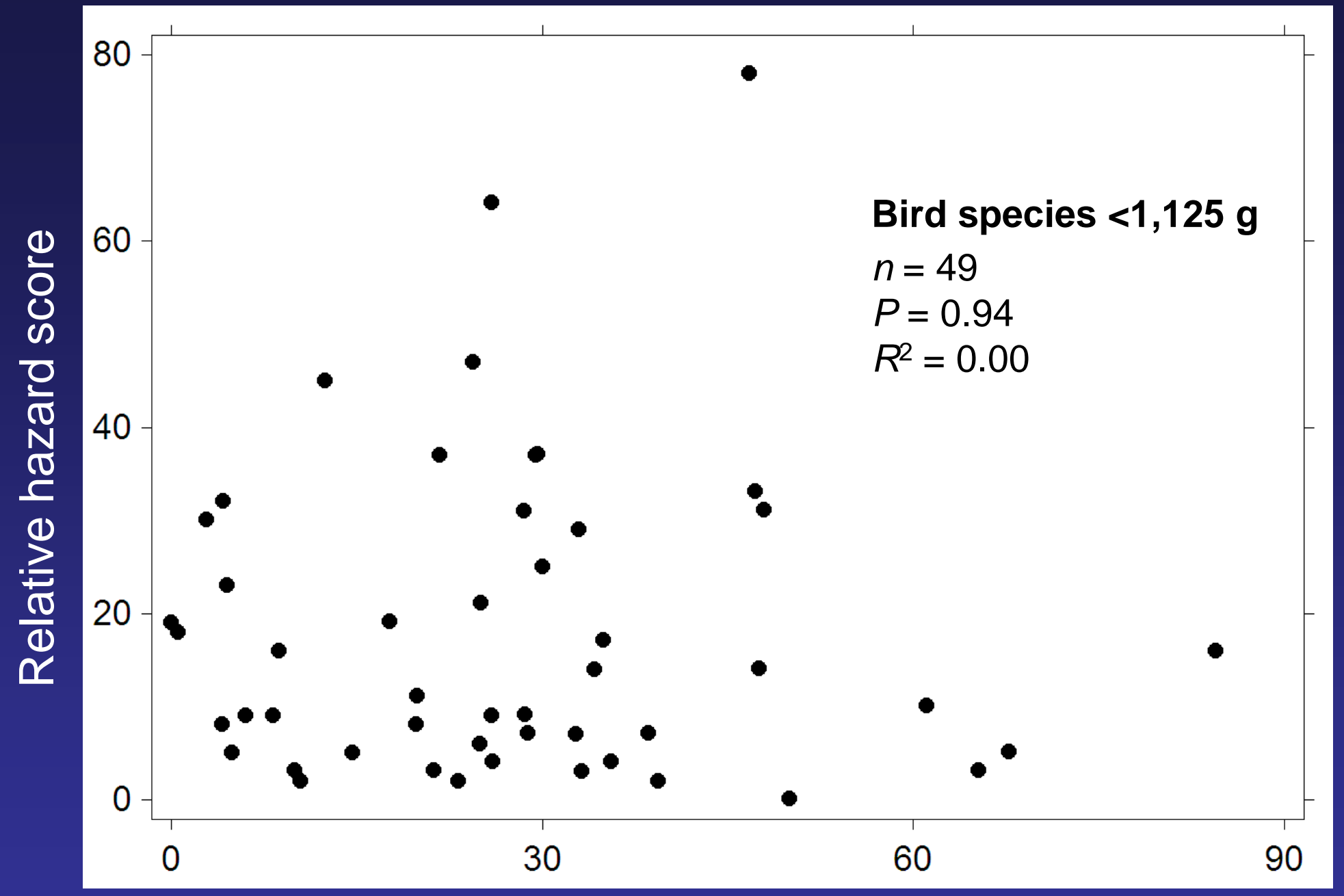

$\%$ of strikes involving multiple birds 


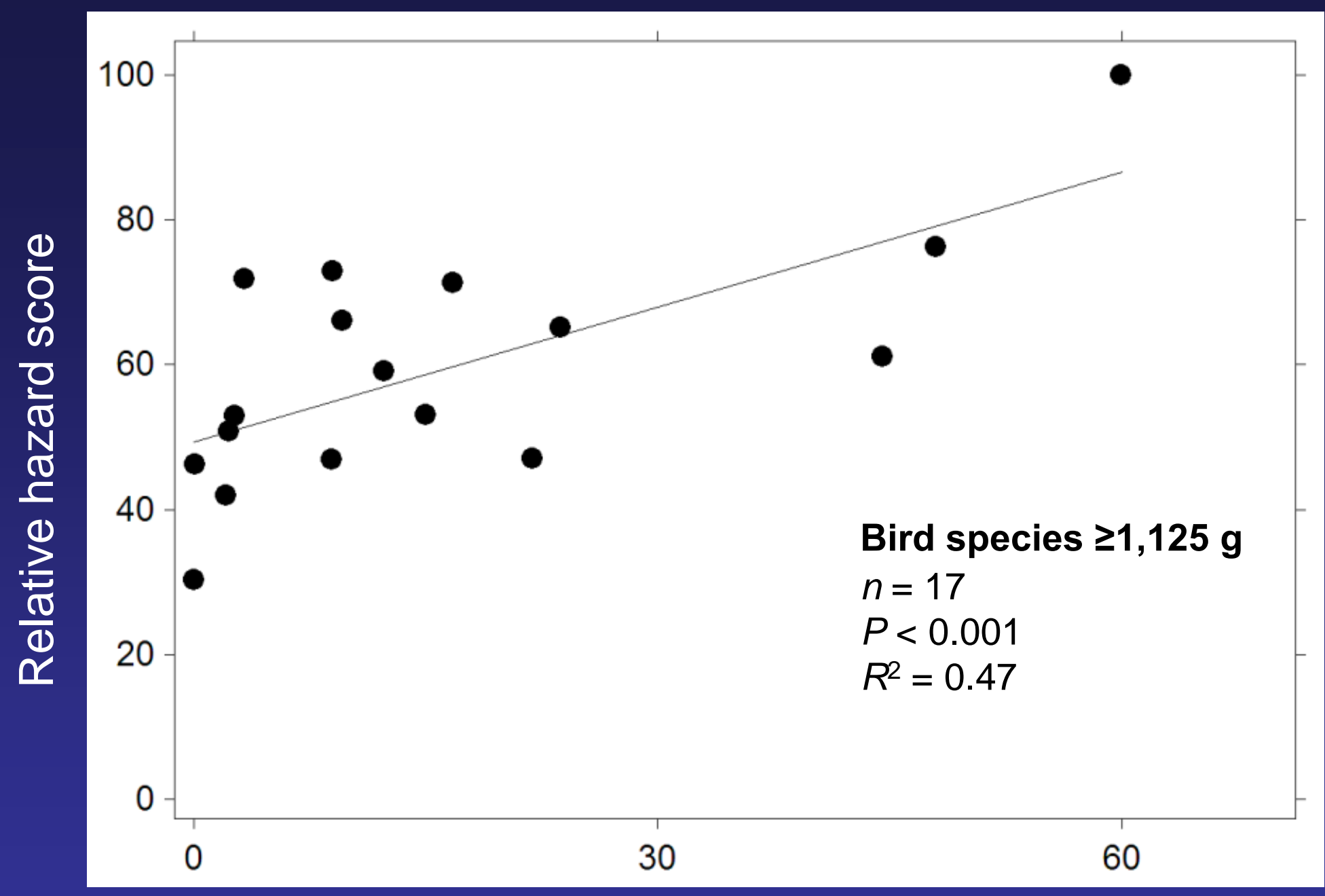

$\%$ of strikes involving multiple birds 


\section{Conclusions-confirmed}

$\rightarrow$ Large mammals are extremely dangerous on airports

$\rightarrow$ The top 3 most hazardous species are large mammals

$\rightarrow$ Overall, large $(>1 \mathrm{~kg}$ ) birds are most dangerous to aircraft

t Median body mass for species in damaging strikes $=1,125 \mathrm{~g}$

$\rightarrow$ Median body mass for species in non-damaging strikes $=97 \mathrm{~g}$

t Importance of proper management of stormwater retention ponds and other water bodies

$t_{10}$ of 15 most hazardous birds were associated with water
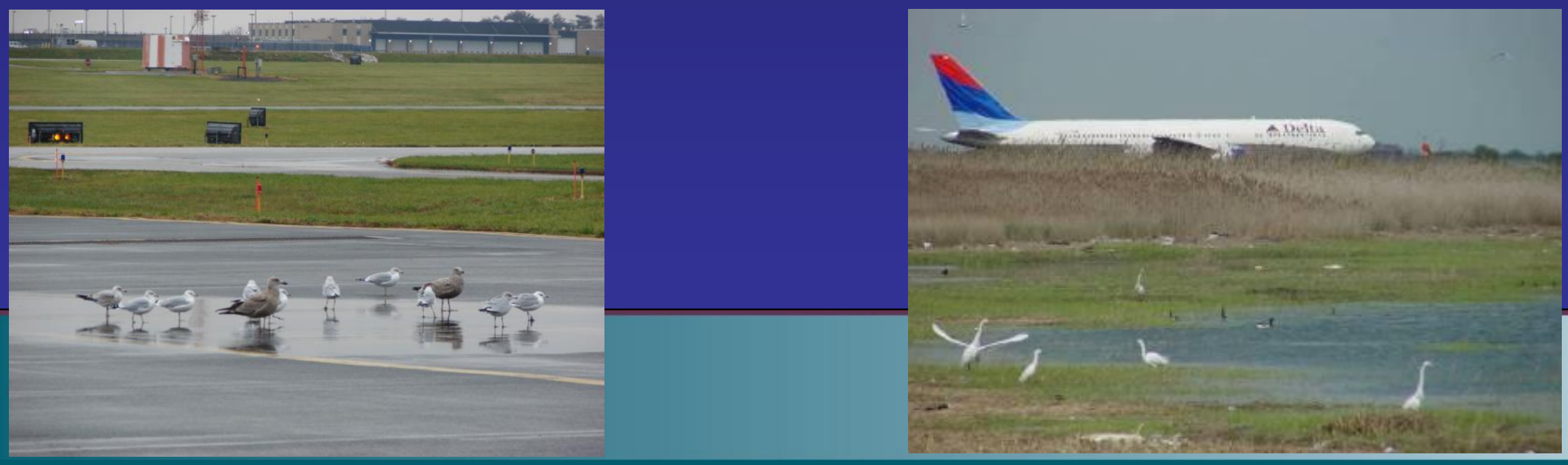


\section{Conclusions-new}

A Avian body mass was strongly associated with relative hazard score, but not for species $\geq 1,125 \mathrm{~g}$

$\rightarrow$ Relative hazard score increased when multiple birds involved in strike, but only for species $\geq 1,125 \mathrm{~g}$

$\dashv$ For small birds, are only very large flocks are especially dangerous?

t The effect of avian body density is swamped by body mass
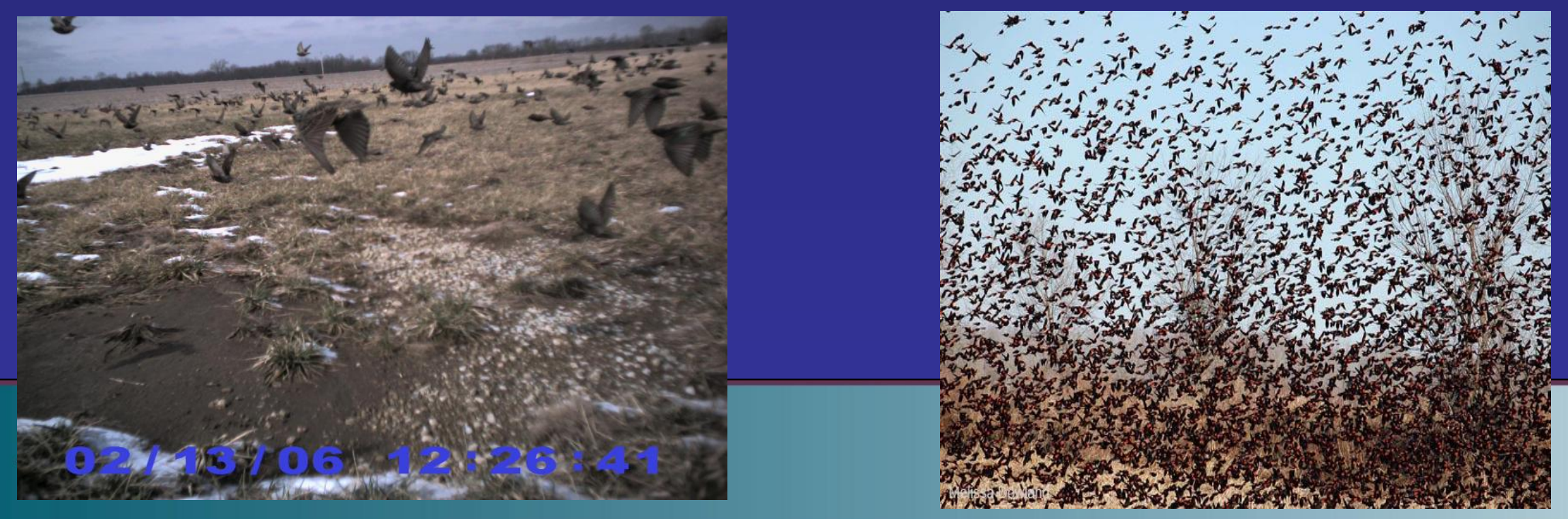


\section{Take-home messages}

t Zero-tolerance for deer and other large mammals on the airfield $\rightarrow$ Fences!

$\rightarrow$ Geese and other waterbirds are often the most hazardous species at airports

$\rightarrow$ Prioritize habitat management for highest-hazard species/groups present at the airport

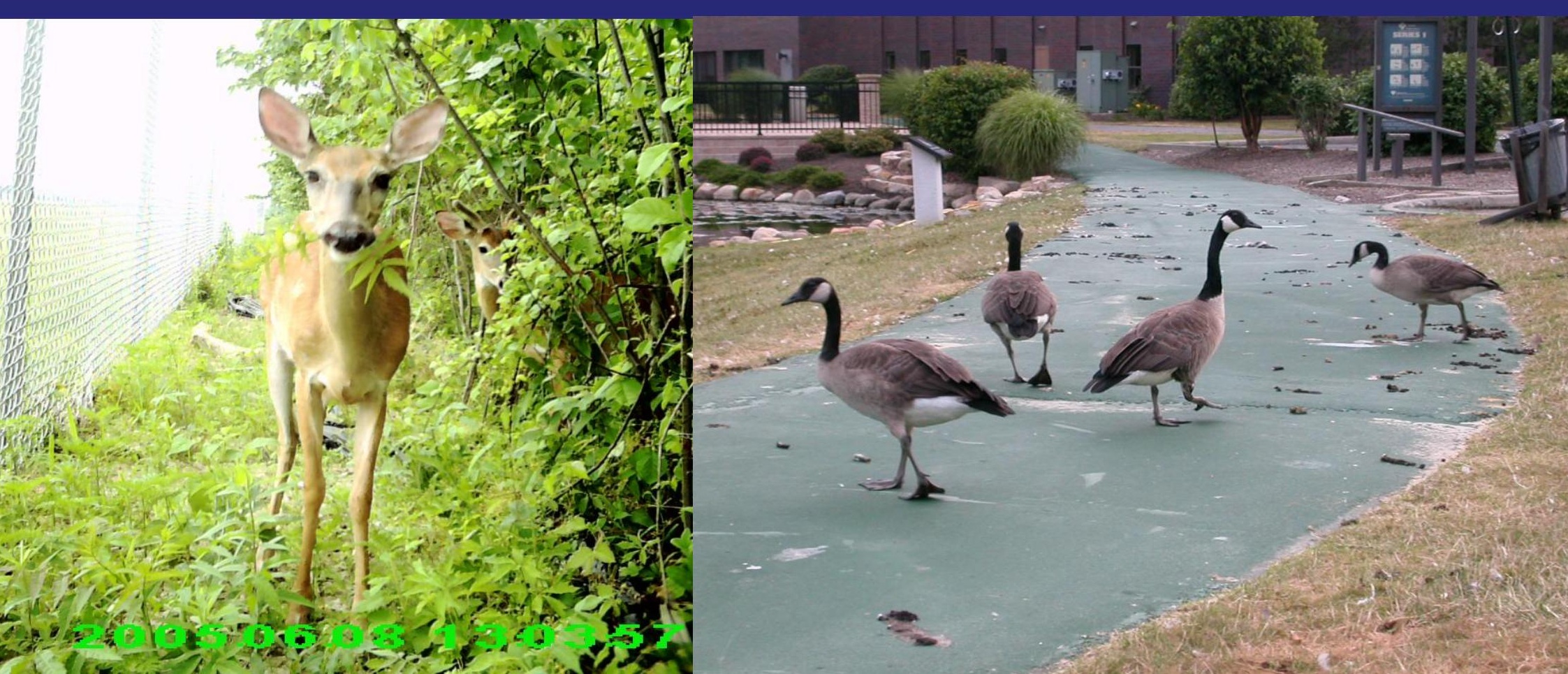




\section{For further reading...}

DeVault, T.L., J.L. Belant, B.F.

Blackwell, and T.W. Seamans.

Interspecific variation in wildlife hazards to aircraft: Implications for airport wildlife management. Wildlife Society Bulletin: In Press.

Biondi, K.M., J.L. Belant, J.A. Martin, T.L. DeVault, and G. Wang. White-tailed deer incidents with U.S. civil aircraft. Wildlife Society Bulletin: In Press. 